\title{
IMAGEN ESTEREOTIPADA DE LAS MEXICANAS Y LOS MEXICANOS ${ }^{89}$ Adria Ailev Murillo González
}

Sumario: I. Introducción. II. Hipótesis. III. Argumentos de soporte, En dirección de los estereotipos negativos. IV. En dirección de los estereotipos positivos. VI. Conclusiones

\section{Resumen}

En este documento, se examinan dos hipótesis que intentan explicar la "forma de actuación" de las (os) Mexicanas(os) y sus consecuencias, con la propuesta de la participación individual y organizada para resolver los múltiples problemas que aquejan a la colectividad y establecer las condiciones para que las futuras generaciones desarrollen armónicamente todas sus facultades y con ello formar parte de una generación de mexicanos; que se sume a los que han trascendido con una imagen positiva del ser humano, dejando para siempre en el olvido las desafortunadas imágenes estereotipadas negativas que subsisten hoy en día, en número no despreciable.

\begin{abstract}
In this document, two hypotheses, which are examined, try to explain the "Mexican behavior" and its consequences, with the proposal of the individual or organized participation in order to resolve the multiple problems facing the community and establish conditions so that future generations can develop all their abilities harmoniously and thus be part of a new generation of Mexicans which incorporate to those who have transcended with a positive image of the human being, leaving behind the unfortunate negative stereotypical images that still exist today, in non-negligible number.
\end{abstract}

\section{Introducción}

En el presente Siglo XXI, aún cuando no se debe generalizar, el mexicano al igual que otros nacionales de otros países son producto de su entorno, su historia y su educación. Tratar de escudriñar el porqué de su actuación y los resultados consecuentes, no es tarea fácil. De la lectura de los textos proporcionados ${ }^{90}$ sin profundizar en otras lecturas 0 resultados de investigación sobre el tema, se puede elaborar a priori algunas hipótesis sobre las cuales argumentar de manera tal que se demuestren o no en su contenido, o simplemente resulten nulas. Lo que aquí se examina y plantea

\footnotetext{
${ }^{89}$ Ensayo para la Asignatura Expresión Verbal en el Ámbito Profesional EVAP, siguiendo el Guión: Elaborar hipótesis en relación a la "forma de actuación" de la/ del mexicana(o) y sus consecuencias

90 Ver Bibliografía
} 
tiene como finalidad tratar de comprender algunos de los aspectos positivos y los negativos asociados a los mexicanos.

\section{Hipótesis}

Las imágenes positivas o negativas estereotipadas del mexicano siguen vigentes.

Hipótesis 1 " la imagen de macho mexicano, desobligado, borracho, jugador es producto de múltiples desafortunadas experiencias recogidas en la literatura, en la prensa ,en los archivos policiacos $o$ en guiones cinematográficos “

Hipótesis 2

"la imagen del mexicano esforzado,sobrio,practicante de deportes o de las artes es producto de múltiples afortunadas experiencias que son corroboradas en sus acciones o por sus aportes a las ciencias o a las obras filantrópicas, por su desempeño o sus aportes en el ejercicio de su profesión ya sea en el sector publico privado o social.

\section{Argumentos de soporte}

\section{En dirección de los estereotipos negativos (Primera Hipótesis)}

Al parecer, una de las imágenes más estereotipadas es quizá la del macho mexicano, desobligado, borracho, jugador que es producto de múltiples desafortunadas experiencias recogidas en la literatura, en la prensa ,en los archivos policiacos o en guiones cinematográficos.

Esta postura tampoco le es ajena a los autores de las lecturas proporcionadas como Samuel Ramos quien señala que:“...la nacionalidad mexicana se fue la respaldan los autores de las lecturas proporcionadas y lo que en ellas se menciona, como Samuel Ramos quien señala que :“...la nacionalidad mexicana se fue haciendo a lo largo del siglo XIX sobre la base ...de experiencias colectivas desfavorables. Cómo ... la independencia... la guerra del 47...Continua el desequilibrio interno con la lucha de los partidos, .... Otro golpe ... el Imperio de Maximiliano... Las frecuentes guerras civiles ...El orden Porfiriano favorece.... a la clase que está en el poder. La educación pública es precaria, la cultura superior insuficiente. No es pues, extraño ...una valoración negativa de la nacionalidad... las opiniones del extranjero que, generalmente... exageradas, representan a México como un país atrasado, sumido constantemente en el desorden y la barbarie. Desde la campaña ..Poinsset, hasta las campañas de las agencias noticiosas norteamericanas ...sobre la Revolución de 1910, ... surge la desconfianza de los mexicanos 
unos respecto a otros, se debilita su espíritu de solidaridad y de cooperación social y los hombres se sienten atenidos a sus recursos individuales..."91

Igualmente Denisse Dresser por un lado abona en dirección del contenido de la primera hipótesis, al mencionar que :

“.....alguna vez el periodista Julio Scherer García le pidió a Ernesto Zedillo que le hablara de su amor por México. Le sugirió que hablara del arte, de la geografía, de la historia del país. De sus montañas y valles, sus volcanes, sus héroes y sus tardes soleadas. El ex presidente no supo que contestar. Hoy es probable que muchos mexicanos tampoco sepan como hacerlo. Hoy el pesimismo recorre al país e infecta a quienes entran en contacto con él. México vive obsesionado con el fracaso. Con la victimización. Con todo lo que pudo ser y no fue. Con lo perdido, lo olvidado, lo maltratado. México estrena el vocabulario del desencanto. Se siente en las sobremesas, se comenta en las calles, se escucha en los taxis, se lee en las pintas, se lamenta en las columnas periodísticas, se respira en los lugares donde aplaudimos la transición y ahora padecemos la violencia."..... ${ }^{92}$

Por su parte Octavio Paz ${ }^{93}$ describe y/o pretende desentrañar y justificar la imagen estereotipada negativa del mexicano de la primera hipótesis

“...el Solitario mexicano ama las fiestas y las reuniones públicas. Todo es ocasión para reunirse. Cualquier pretexto es bueno para interrumpir la marcha del tiempo y celebrar con festejos y ceremonias hombres y acontecimientos. Somos un pueblo ritual. Y esta tendencia beneficia a nuestra imaginación tanto como a nuestra sensibilidad, siempre afinadas y despiertas. ... En pocos lugares del mundo se puede vivir un espectáculo parecido al de las grandes fiestas religiosas de México, con sus colores violentos, agrios y puros, sus danzas sus ceremonias, fuegos de artificio, trajes insólitos y la inagotable cascada de sorpresas de los frutos, dulces y objetos que se venden esos días en plazas y mercados.".......

Asimismo continua diciendo, .."Durante esos días el mexicano silencioso silba,grita,canta,arroja petardos, descarga su pistola al aire. Descarga su alma. Y su grito, como los cohetes que tanto nos gustan, sube hasta el cielo, estalla en una explosión verde,roja,azul y blanca y cae vertiginoso dejando

\footnotetext{
${ }^{91}$ Samuel Ramos. "El complejo de inferioridad". en Roger Bartra (selección y prólogo). Anatomía del mexicano. México: Random House Mondadori, 2005, pp 113 prf2

92 Dresser, Denisse "El país de uno. Reflexiones para entender y cambiar a México, México,Ed.,Aguilar, 2011,pp. 13 prf 1

${ }_{93}$ Paz,Octavio ,"El laberinto de la soledad, Capítulo "Todos Santos, Día de Muertos",1996, pp.51, prf 1
} 
una cauda de chispas doradas.....en ocasiones, es cierto, la alegría acaba mal: hay riñas,injurias, balazos, cuchilladas. También esto forma parte de la fiesta. Porque el mexicano no se divierte: quiere sobrepasarse, saltar el muro de soledad que el resto del año lo incomunica..... ${ }^{94}$ "

Desafortunadamente en nuestros días ${ }^{95}$ podemos ver cercanos a nosotros o a la distancia en notas periodísticas o en imágenes televisadas de noticieros locales o nacionales escenas de violencia intrafamiliar donde "el jefe de familia" adopta el papel de "macho mexicano" y comete atropellos en contra de su esposa o hijos, con consecuencias irreversibles, al provocar la muerte o mutilación de algunos de sus integrantes.

\section{En dirección de la Segunda Hipótesis}

Afortunadamente, existe la imagen estereotipada positiva del mexicano esforzado, sobrio, practicante de deportes o de las artes, producto de múltiples afortunadas experiencias que son corroboradas ${ }^{96}$ en sus obras o por sus aportes a las ciencias o a las obras filantrópicas, por su desempeño o sus aportes en el ejercicio de su profesión ya sea en el sector publico privado o social. En este sentido, de las lecturas proporcionadas encontramos las explicaciones de Denisse Dresser que nos dice:

"La única esperanza ante el diagnóstico contenido en este libro ${ }^{97}$,se encuentra en esos mexicanos-empeñosos, valerosos,combativos---que se

\footnotetext{
${ }_{95}^{94}$ Paz,Octavio,op.cit., pp. 53 prf. 2

${ }^{95}$ En un 30 por ciento han incrementado las denuncias por violencia familiar en contra de menores y adultos, declaró el procurador de la Defensa del Menor, la Familia y el Indígena del DIF municipal, Salvador Hernández Martínez. [Consultado en http://www.imagendelgolfo.com.mx/resumen.php?id=41012158]

Atiende Ciudad de México a más de mil 276 víctimas de violencia familiar. [Consultado en http://www.sdpnoticias.com/gdf/2014/06/26/atiende-ciudad-de-mexico-a-mas-de-mil-276-victimasde-violencia-familiar ]

${ }_{96}$ Científico mexicano gana "premio Nobel" de Alimentación. [Consultado en http://www.eldiariodecoahuila.com.mx/notas/2014/6/18/cientifico-mexicano-gana-premio-nobelalimentacion-439998.asp] Los cien de Paz, homenaje al premio Nobel mexicano [Consultado en http://www.sexenio.com.mx/veracruz/articulo.php?id=6832] Mención especial merece el incremento sostenido de la participación de las mujeres en las justas deportivas. Este incremento nos ha permitido gozar de glorias como las alcanzadas por Ana Gabriela Guevara, quien logró la medalla de oro en el Campeonato Mundial de Atletismo en el año 2003; la actual campeona de racquetbol, Paola Longoria, que ha ganado 34 títulos seguidos con 137 victorias consecutivas, y así pudiéramos abordar una larga lista con nombres como los de Paola Espinoza, Lorena Ochoa e Iridia Salazar.[Consultado en http://www.elheraldodesaltillo.mx/opinion/p2_articleid/92247]

${ }_{97}$ Que coincide con el contenido de la Hipótesis número1 el de los aspectos negativos del mexicano(a)
} 
niegan a participar en el colapso moral de su país. Los que insisten en la transparencia en lugar de la opacidad. Los que optan por la construcción en vez de la destrucción. Los que se niegan a ser parte del desmantelamiento. Los que quieren enfrentarse al viejo problema de cómo defender intereses particulares mientras pelean colectivamente por el bien común. Y que ante lo contemplado, rehúsan esquivar la mirada o perder la fe. Como escribiera Margaret Mead: "Nunca dudes que un pequeño grupo de ciudadanos pensantes y comprometidos puede cambiar al mundo. Es la única cosa que lo ha hecho"98

En este apartado cabe señalar que coincido con Dresser en lo que respecta a la importancia de la participación organizada de los ciudadanos para defender los intereses que en múltiples ocasiones son atropellados por las propias autoridades y/o ciudadanos faltos de valores y/o de responsabilidad como funcionarios públicos, en detrimento del medioambiente, la salud, la educación, la seguridad y la integridad física y espiritual de las personas.

Por su parte, en el mismo tenor Carlos Monsiváis en su ensayo "La identidad nacional ante el espejo" comenta:

“.... que la normatividad en México hace que las expresiones populares que se divulgan como "identidad nacional" sean, en primer lugar las de la capital de la república(confrontar la secuela fílmica: Nosotros los pobres, Mecánica Nacional, La Pulquería, ....no hay diferencias perceptibles entre la visión comercial de "cultura urbana" y la de "identidad"...... Por eso ...lo difícil del...uso del término "identidad nacional", por la enorme mutabilidad que varía según funcione en barrios o vecindades o colonias residenciales 0 condominios o unidades habitacionales de burócratas o colonias populares o ciudades perdidas o rancherías o poblados indígenas o zonas fronterizas. México es, a la vez, un país mas unificado y mas plural de lo que se piensa...... 99

Es decir, la identidad de un país es un término complicado de explicar pues parafraseando a Monsiváis, "la identidad de un país no es una esencia ni el espíritu de objetos inertes, sino de historia viviente que nunca se acepta del todo."

En contrapartida a lo señalado en favor de la imagen estereotipada negativa (Primera hipótesis), Samuel Ramos en su obra "El Complejo de inferioridad",

\footnotetext{
${ }^{98}$ Dresser,op.cit., pp19 prf 3,

${ }^{99}$ Monsiváis, Carlos "La identidad ante el espejo". en Roger Bartra (selección y prólogo). Anatomía del mexicano. México:,2005,Random House Mondadori, pp.297prf2
} 
abona a favor de la imagen estereotipada positiva del mexicano (Segunda hipótesis) a saber:

"Tengo la impresión de que se ha insistido demasiado en los rasgos anómalos del carácter mexicano, que justamente por su anomalía son los mas impresionantes a primera vista. Es cierto que la interpretación de tales anomalías era una etapa indispensable para descubrir lo que hay de ficción en nuestro carácter nacional. Pero me parece que ha llegado el momento de considerar las manifestaciones, por decirlo así, normales de la vida mexicana. Es en estas donde puede descubrirse el fondo auténtico de nuestro ser, completando así el bosquejo hasta ahora trazado que de otro modo sería unilateral y en consecuencia también falso... "100

\section{Conclusiones}

- Para tratar de descubrir la esencia de las mexicanas y de los mexicanos, se deberá tomar en cuenta además de los acontecimientos históricos, las diversas formas de conducta, virtudes y defectos, clases sociales y/ o económicas, expresiones culturales y artísticas pero sobre todo, siguiendo a Dresser, "hacer una declaración de fe, para ser ciudadanos participativos, con una filosofía personal basada en la premisa de que la acción individual y colectiva si sirve para resolver los múltiples problemas que aquejan a la colectividad".

- En otras palabras, se requiere que los mexicanos tomemos conciencia de la importancia de participar en mejorar no solo en lo individual (a través de la educación, la cultura, y el desarrollo de las artes) si no también a través de acciones colectivas para mejorar nuestro entorno (cuidado de los espacios públicos como transporte, parques, bibliotecas, centros comunitarios o deportivos).

- Establecer las condiciones para que las futuras generaciones desarrollen armónicamente todas sus facultades y con ello formar parte de una generación de mexicanos; que se sume a los que han trascendido con una imagen positiva del ser humano, dejando para siempre en el olvido las desafortunadas imágenes estereotipadas negativas que subsisten hoy en día, en número no despreciable.

${ }^{100}$ Ramos, Samuel, op.cit.pp119,prf 2 
- Del examen de las lecturas realizadas queda evidenciado que en nuestros días las imágenes positivas o negativas estereotipadas del mexicano siguen vigentes, y al interior de cada uno, la lucha para vivir $y$ cambiar, cumplir para exigir y no solo presenciar...para acuñar un conjunto de afirmaciones que sean antídoto contra la apatía y la indiferencia, es decir, se requiere de la participación para terminar con todo lo nocivo o perjudicial que abona día tras día al material que se lee en los periódicos o se percibe en las redes o en los noticieros transmitidos por radio y televisión.

\section{Bibliografía}

Monsiváis, Carlos, "La identidad ante el espejo", en Roger Bartra (selección y prólogo). Anatomía del mexicano. México,Ed.,Random House Mondadori, 2005,pp. 295-301.

Dresser, Denise, "El país de uno. Reflexiones para entender y cambiar a México", México, Ed. Aguilar, 2011

Paz, Octavio, "El laberinto de la soledad". México, Ed. Fondo de Cultura Económica, 1996.

Ramos,Samuel, "El complejo de inferioridad". en Roger Bartra (selección y prólogo). Anatomía del mexicano. México,Ed.Random House Mondadori,2005, pp.109-120. 